\title{
Hypothalamo-Pituitary Adrenocortical Function in Nephrotic Patients during Corticoid Treatment
}

\author{
Kenji MATSUOKA \\ The Second Department of Internal Medicine, Kyoto Prefectural University of \\ Medicine, Kyoto, Japan (Director : Professor Susumu Marumoto)
}

The inevitable and harmful suppression of hypothalamo-pituitary adrenocortical function results from the corticoid administration. In order to check the iatrogenic adrenocortical dysfunction and to prevent this side effect, the periodical ACTH-Z tests before, during and after treatment for the 13 nephrotic patients were performed.

The adrenocortical function was examined by daily urinary excretion of PorterSilber chromogen, Zimmermann chromogen and 17-KGS. Functional reserve of hypothalamo-pituitary adrenocortical system was examined by response of intramuscular injection of 25 units of ACTH-Z and then by response to oral administration of $3 \mathrm{gm}$ of SU-4885.

Both the daily urinary excretion of corticosteroids and the response to ACTH-Z in the nephrotic patients before corticoid treatment showed no significant difference from those in normal adults. Poor responses to SU-4885 were observed in four patients before treatment.

There was no correlation between the daily excretion of the response value to ACTH-Z and the results of renal function in the patients.

In the course of treatment with betamethasone, urinary corticosteroid promptly decreased. However, the response to ACTH-Z was gradually depressed. The mean "adrenocortical response value" in terms of the increments in urinary Porter-Silber chromogen showed the following values : $20.1 \pm 10.9 \mathrm{mg}$ before the corticoid treatment, $16.1 \pm 7.4$ $\mathrm{mg}$ in 2 weeks after administration, $10.0 \pm 6.9 \mathrm{mg}$ in a month, $7.9 \pm 5.9 \mathrm{mg}$ in 2 months, $7.3 \pm 5.0 \mathrm{mg}$ in 3 months, $4.6 \pm 4.9 \mathrm{mg}$ in 4 months, $12.0 \pm 5.1 \mathrm{mg}$ in a week after discontinuing betamethasone and $14.6 \pm 7.5 \mathrm{mg}$ a month later. Similar changes in the adrenocortical response value from the increments in Zimmermann chromogen or 17-KGS in urine were observed. However, Porter-Silber chromogen was verified to be the most reliable measurement for tracing the response of adrenal cortex during the betamethasone treatment.

After the dosage of betamethasone tapered at $1.0 \mathrm{mg}$ or less per day, the daily excretion of urinary corticosteroids and the response value to ACTH-Z were gradually elevated.

After discontinuation of corticoid therapy, the recovery of suppressed adrenocortical function was observed in all cases. A rebound phenomenon was observed within a 
week. The response value to ACTH-Z after discontinuing corticoid therapy also showed improvement but showed no significant difference from the level before treatment of corticoid or from normal range. The response to SU-4885 in only three cases were significantly reduced.

No inverse correlation was observed between the daily corticosteroids excretion, as well as the response value to ACTH-Z after treatment, and the sum of administered doses of betamethasone, or the duration of corticoid therapy. Throughout the course of treatment, there was no case who showed clinical manifestations or laboratory findings indicating adrenocortical insufficiency.

From these observations, it is concluded that the ACTH-Z test before, during and after treatment with betamethasone is a reliable test to evaluate the adrenocortical reserve. The withdrawal adrenocortical insufficiency will be safely avoided in so far as "adrenocortical response value" to ACTH-Z remains within the above-mentioned ranges.

(See pp. 1018 1032) 


\title{
ネフローゼ症候群の合成コルチコイド療法時の 間脳下垂体副腎皮質機能動態
}

\author{
京都府立医科大学第二内科 (指導 丸本晋教授) \\ 松岡謙二
}

（昭和46年12月 3 日受付）

\begin{abstract}
ベタメサゾン治療の症13症例の治療前中後における尿 corticosteroid（以下 CS）排泄量を測定し， AGTH-Z, SU-4885 負荷による間脳下垂体副腎皮質予備能の推移を経時的に追求した。治療前のネ症に は副腎皮質機能低下を認めなかつた。治療中，CS 排泄量は急速に，予備能は徐々に低下した。しか し corticoid 投与による機能抑制は可逆的で，投与中止とともに CS 排泄量は反撥的に増化し，予備能 の回復正常化をみた. 治療終了 1 週後の予供能と corticoid 投与の量, 期間との間に相関を認めない.
\end{abstract}

\section{I ま がき}

Hench, Kendall1) (1949) らがコーチゾンを関節リウマチの治療にはじめて用い,ついで 1950年には Thorn'2)，Farnsworh ${ }^{3)}$ らによつて腎疾患の治療に導入された.

その後はコーチゾンに代る新合成剤が相ついで開発されたが，そのためにすぐれた治療効果を発揮するば かりでなく，その副作用を軽減するために並々なら好努力が払われた．合成コルチコイドは種々の型の腎疾 患の治療に試みられたが，ネフローゼ症候群（以下ネ症と略す）に著効をおさめ，完全寬解に導入させるて とさえ可能であるとてろから，もつぱらネ症治療剤として重要な地位を獲得するに至つた。

この合成コルチコイドのネ症に対する治療はいわゆるホルモン羭としての補償療法と異なり, 生理的量を はるかに超えた量が投与され，その薬理的作用を期待したとてろの治療法である.したがつてての生理的量 を超えたコルチコイドの投与はすぐれた治療効果を示すが，一方において多彩な副作用をも出現するてとに なる。しかもその適応の多くが原因療法といらよりはその抗炎症作用を期待した対症療法的色彩がつよいの で, 治療の実際面では結果的に長期かつ大量になるととも少なくない.しかもその多くは治療終了後におて るであろう副腎クリ一ゼの出現を恐れて，ともすれば消極的な漸減療法の形をとり，あるいはさまざまな副 腎皮質機能不全の防止策の試みがされるのである。しかもその防止策のほとんどは客観的な実験成績や臨床 成績などの厳密な裏づけもなしに実行されるととが多い，てのように副作用への対策が安易に論じられる以 前に，合成コルチコイド治療にあたつて患者の間脳下垂体副䐌皮質機能を客観的に認識するてとが必要であ ると考朰れるので, 長期の合成コルチコイド療法を余儀なくされるネ症を対象として，ベタメサゾン治療 前，中，後にわける間脳下垂体副腎皮質系の機能動態を追求し，てれを客観的にとらえるためにての研究を おてなつた，副腎皮質機能不全に対する無䭾のない効果的な防止策をてのような客観性をもつた認識から導 きうると考光たからである.

\section{III 研究の対象と測定の方法}

\section{(A) 対象}

いずれも成人ネフローゼ症候群治療研究会の診断基準を満足する13症例で, 肝機能障害の合併, 高度の腎 機能障害例も含まない，との13症例には，ベタメサゾン治療は再発に対する再治療をも含めて17治療をおて 
ない, うち著効, 有効併せて 13 , 無効 4 であつた. ベタメサゾンは他の治療薬剤を併用することなく, 単独 投与し, その初回量 4 ないし $6 \mathrm{mg}$ を, DiRaimondo ${ }^{4)}$ ，井林ら ${ }^{5)}$ の推奨する朝 3 , 昼 2 , 夕 1 の漸娍 3 分割法 により連日投与した. 初回量を 2 ないし 4 週間維持し，以後は尿蛋白の減少を指標として，夜 $\rightarrow$ 㡺 $\rightarrow$ 朝の順 で漸次 $0.5 \mathrm{mg}$ まで娍量してから投与を中止した。 ベタメサゾン投与は個々の症例によつて異なり，投与総量 は203.5から509.75mg，投与日数は76から535日にわたつた。（Table 1)

Table 1

\begin{tabular}{|c|c|c|c|c|c|c|c|c|c|c|c|c|c|c|c|c|c|c|c|c|}
\hline \multirow{3}{*}{ Case } & \multicolumn{9}{|c|}{ Before Treatment } & \multicolumn{9}{|c|}{ After Treatment } & \multirow{3}{*}{$\mid \begin{array}{c}\text { Sum of } \\
\text { Admini- } \\
\text { st. Doses } \\
\text { of B-M. } \\
(\mathrm{mg})\end{array}$} & \multirow{3}{*}{$\begin{array}{l}\text { Durati- } \\
\text { on of } \\
\text { B-M. } \\
\text { Tnerapy } \\
\text { (days) }\end{array}$} \\
\hline & \multicolumn{3}{|c|}{$\begin{array}{c}\text { Daily } \\
\text { Excretion }\end{array}$} & \multicolumn{3}{|c|}{$\begin{array}{l}\text { Response } \\
\text { Value to } \\
\text { ACTH-Z }\end{array}$} & \multicolumn{3}{|c|}{$\begin{array}{l}\text { Response } \\
\text { Value to } \\
\text { SU-4885 }\end{array}$} & \multicolumn{3}{|c|}{$\begin{array}{c}\text { Daily } \\
\text { Excretion }\end{array}$} & \multicolumn{3}{|c|}{$\begin{array}{l}\text { Response } \\
\text { Value to } \\
\text { ACTH-Z }\end{array}$} & \multicolumn{3}{|c|}{$\begin{array}{l}\text { Response } \\
\text { Value to } \\
\text { SU-4885 }\end{array}$} & & \\
\hline & P.S. & Z. & KGS & P.S. & $\mathrm{Z}$. & KGS & P.S. & $\mathrm{Z}$. & KGS & P.S. & $\mathrm{Z}$. & KGS & P.S. & $\mathrm{Z}$. & KGS & P.S. & $\mathrm{Z}$. & KGS & & \\
\hline 1.H.M. & 8.6 & 3.1 & 8.8 & 37.6 & 3.1 & 58.2 & & & & 4.1 & 2.7 & 5.2 & 6.7 & 3.2 & 17.0 & & & & 332.0 & 142 \\
\hline 2. T.T. & 5.2 & 3.8 & 9.4 & 12.3 & 8.0 & 2.4 & & & & 5.4 & 2.8 & 16.7 & 8.3 & 0.9 & 18.6 & & & & 266.5 & 105 \\
\hline 3. T.K. & & & & & & & & & & 6.4 & 4.7 & 7.2 & 9.1 & 0.4 & 19.7 & & & & 241.5 & 200 \\
\hline & 7.9 & 3.5 & 8.3 & 37.8 & 6.9 & 49.1 & & & & & & & & & & & & & & \\
\hline 4. Y.O. & 3.8 & 1.6 & 9.6 & 22.0 & 1.3 & 311.6 & 4.9 & 6.1 & \begin{tabular}{l|l}
1 & 3.8
\end{tabular} & 2.3 & 2.9 & 4.5 & 25.3 & 2.5 & 33.9 & -0.5 & 1.2 & 4.8 & 257.0 & 94 \\
\hline & 5.1 & 1.5 & 7.9 & 25.3 & 1.9 & 37.8 & $\begin{array}{ll}3.7 \\
1.7\end{array}$ & 2.1 & \begin{tabular}{l|l}
1 & 4.0
\end{tabular} & 1.7 & 2.1 & 4.0 & 7.0 & 0.7 & 18.1 & & & & 334.0 & 76 \\
\hline & 4.0 & 1.7 & 2.1 & 7.0 & 0.7 & 18.1 & & & & & & & & & & & & & 463.25 & 535 \\
\hline 5. T.M. & 6.2 & 4.0 & 10.0 & 5.5 & 3.3 & 13.0 & & & & & & & & & & & & & 271.0 & 100 \\
\hline $6 . \mathrm{K} \cdot \mathrm{Y} \cdot$ & 7.2 & 6.1 & 22.0 & 28.2 & 2.9 & 22.0 & & & & 7.3 & 3.3 & 15.0 & 14.0 & 11.4 & 35.3 & & & & 227.0 & 99 \\
\hline 7.K.S. & 4.8 & 1.1 & 11.0 & 15.6 & 3.0 & 11.7 & & & & 5.1 & 2.2 & 15.1 & 11.9 & 0.5 & 11.3 & & & & 270.0 & 172 \\
\hline 8. Y.K. & 4.4 & 6.5 & 11.8 & 10.1 & 10.2 & 15.4 & & & & & & & & & & & & & 466.5 & 195 \\
\hline 9.K.W. & 6.0 & 2.6 & 13.6 & 37.1 & 6.0 & 17.0 & 17.3 & 2.2 & 217.1 & 2.0 & 2.1 & 3.7 & 11.2 & 1.9 & 13.2 & & & & 203.5 & 115 \\
\hline & 3.5 & 2.0 & 10.6 & 25.3 & 4.7 & 27.1 & & & & & & & & & & & & & 230.5 & 224 \\
\hline $10 . \mathrm{S} \cdot \mathrm{Y}$ & 5.8 & 2.2 & 7.4 & 17.8 & 2.2 & 11.5 & 12.3 & 5.5 & $\begin{array}{ll}5 & 6.6\end{array}$ & & & & & & & & & & 509.75 & 292 \\
\hline 11. H.T. & 2.1 & 1.8 & 5.2 & 5.6 & 1.5 & 8.9 & 12.1 & 4.7 & 731.8 & 4.4 & 0.6 & 4.9 & 13.3 & 1.8 & 20.3 & & & & 310.5 & 137 \\
\hline 12. H.Y. & 7.4 & 6.4 & 10.9 & 11.01 & 13.0 & 10.4 & & & & 2.5 & 2.3 & 5.1 & 13.3 & 2.4 & 18.4 & & & & 478.5 & 169 \\
\hline 13. H.K. & 5.1 & 7.7 & 10.3 & $22.6 \mid 1$ & 10.0 & 56.1 & & & & & & & & & & & & & & \\
\hline
\end{tabular}

離脱にあたつて ACTH の併用，コルチコイドの間歇投与はおてなつていない．減量中に再燃したものに 対しては原則としてベタメサゾンを増量せず, いつたん漸減中止の上, 暫時の休薬期間をおいて再度初回量 から治療を再開した。

\section{(B) 尿コルチコイド代謝物の測定法}

尿コルチコステロイド（以下尿 CS と略す）の推移はつぎのような測定法によつててれを追求した. すな わち, Reddy-Jenkins-Thorn 法 $(1952)^{6)}$ の熊谷変法 ${ }^{7)}$ とより Porter-Silber chromogen (以下 P.S. Ghr.), Drekter 法の Sobel $(1958)^{8)}$-岡田変法 $(1965)^{9)}$ により Zimmermann chromogen (以下 Z. Chr.), およ び Norymberski 法 (1953) ${ }^{10}$ そより 17-Ketogenic steroid (以下 17-KGS) を測定した.

\section{（G）副腎皮質機能検査法}

P.S. Ghr., Z. Ghr., および 17-KGS の尿24時間排泄量を副腎皮質機能の指標とし，ついで渡辺 $(1960)^{11)}$, 熊谷 (1961) ${ }^{12)}$ らの方法に準じた天然 ACTH-Z 25単位 1 回筋注による ACTH-Z 試験より, 魚住ら (1960) ${ }^{13)}$ の計算式から ACTH-Z 負荷反応量と求め，乙れを副腎皮質予備能とした．さらに河野ら（1964） ${ }^{14)}$ 亿準 ビてメトピロン (SU-4885) 3gm を経口投与して SU-4885 試験をおてない，中村 ${ }^{15)}$ の計算式から SU-4885 負荷反応量を算出し間脳下垂体副腎皮質系予備能とした. 
このようにして間脳下垂体副腎皮質系の機能動態 を求め，症の治療前の副腎皮質機能をしらべ，べ タメサゾン投与開始後 2,4 週， $2 ， 3 ， 4$ ケ月と 以後 1 ケ月でとの時点でベタメサゾンの投与を中断 することなしに ACTH-Z 試験を反復した. ベタメ サゾン投与中止後は，7日目に ACTH-Z 試験，乙 れにひきつづき SU-4885 試験をおてない，以後 1 および 2 ケ月の時点で ACTH-Z 試験によつて機能 回復の追つた。なお検査にあたつて，尿 CS 測定 に干渉するものとして Borushek $(1965)^{16)}$, 三品 $(1965)^{17)}$ ，姜 $(1966)^{18) 19)}$ らか指摘した楽剤の使用 を避けたてとはいうまでもない.

\section{III 成績}

（A）治療前の間脳下垂体副腎皮質機能

（1）尿 CS 24時間排泄量

合成コルチコイド投与前のネ症患者の尿 CS 24 排泄量を Table 1 と Fig. 2 亿示した. Fig. 2 のス クリントーンで健康男女 27 人の尿 CS 24 時間排泄 量の標準偏差域を示した．対象としたネ症のほとん どの症例がスクリントーン域内に含まれる. その平均值と標準偏差とを Table 2 そ示した. 表左端に示し た健康者の24時間排泄量に比べて, P.S. Chr., 17-KGS, Z. Ghr. のいずれも推計学的に有意差はない.

(2) ACTH-Z 試験の反応パターン

Fig. 2 は ACTH-Z ならびに SU-4885 投与による尿中 P.S. Chr. の変化である. スクリントーンは健康

Fig. 2. Hypothalamo-pituitary-adrenocartical response in nephrotic patients before treatment (Porter-Silber Chromogen).

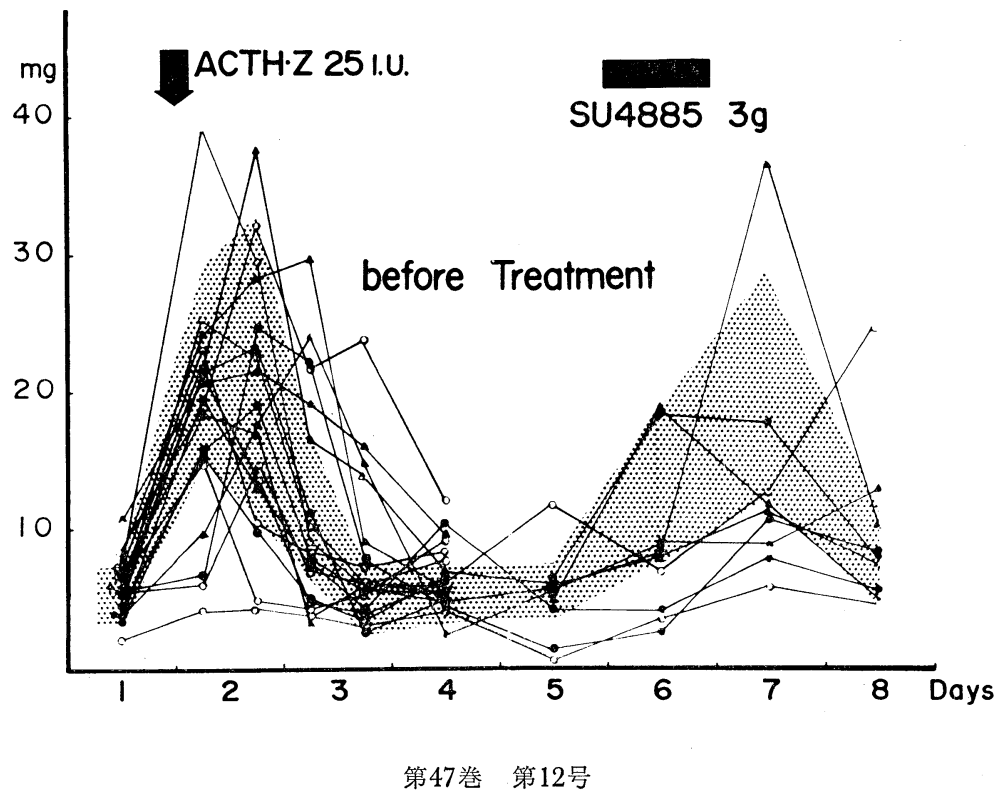


Table 2. Daily excretion of urinary corticosteroids in normal controls and nephrotic patients before, during \& after treatment with betamethasone.

\begin{tabular}{|c|c|c|c|c|c|c|c|c|c|}
\hline & \multirow{2}{*}{$\begin{array}{c}\text { Normal } \\
\text { Control } \\
\text { Group } \\
\text { (mg) }\end{array}$} & \multirow{2}{*}{$\begin{array}{l}\text { Before } \\
\text { Treatment } \\
\quad(\mathrm{mg})\end{array}$} & \multicolumn{5}{|c|}{$\begin{array}{c}\text { During Administration of Betamethasone } \\
(\mathrm{mg})\end{array}$} & \multicolumn{2}{|c|}{ After Treatment $(\mathrm{mg})$} \\
\hline & & & 2 Week & 1 Month & 2 Month & 3 Month & 4 Month & 1 Week & 1 Month \\
\hline P.S. Ghr. & $\begin{array}{l}5.7 \pm 1.5 \\
(27)\end{array}$ & $\begin{array}{l}5.4 \pm 1.6 \\
(16)\end{array}$ & $\begin{array}{c}2.1 \pm 1.5 \\
(10)\end{array}$ & $\frac{2.5 \pm 1.1}{(12)}$ & $\begin{array}{c}1.8 \pm 1.1 \\
(13)\end{array}$ & $2.9 \pm 2.2$ & $2.7 \pm 1.2$ & $\begin{array}{l}4.1 \pm 1.9 \\
(10)\end{array}$ & $\begin{array}{l}5.7 \pm 1.3 \\
\quad(6)\end{array}$ \\
\hline Z. Ghr. & $\begin{array}{l}4.7 \pm 2.0 \\
\quad(27)\end{array}$ & $\begin{array}{c}3.5 \pm 2.0 \\
(16)\end{array}$ & $\mid \begin{array}{c}2.0 \pm 0.9 \\
(10)\end{array}$ & $\begin{array}{c}2.0 \pm 0.8 \\
(12)\end{array}$ & $\begin{array}{c}1.9 \pm 0.9 \\
(12)\end{array}$ & $\begin{array}{c}1.7 \pm 0.5 \\
(7)\end{array}$ & $\frac{2.0 \pm 2.2}{(5)}$ & $\underset{(10)}{2.6 \pm 1.0}$ & $\frac{2.8 \pm 1.0}{(7)}$ \\
\hline 17-KGS & $\begin{array}{l}13.3 \pm 4.7 \\
(16)\end{array}$ & $\begin{array}{l}9.9 \pm 4.1 \\
(16)\end{array}$ & $\begin{array}{c}8.2 \pm 4.1 \\
(10)\end{array}$ & $\begin{array}{c}8.9 \pm 1.0 \\
(12)\end{array}$ & $\begin{array}{l}6.9 \pm 3.45 \\
(11)\end{array}$ & $\begin{array}{c}5.5 \pm 2.3 \\
(7)\end{array}$ & $\begin{array}{c}6.0 \pm 2.5 \\
(5)\end{array}$ & $\begin{array}{l}8.1 \pm 5.0 \\
\quad(10)\end{array}$ & $11.2 \pm 2.2$ \\
\hline
\end{tabular}

Each value is the mean and standard deviation of results.

Numbers in parenthesis means number of cases which were able to be examined.

者15例の標準偏差域であるが，ネ症の AGTH-Z 試験による反応は，1例の反応低下例の他は健康者と大 差のないパターンを示している.

\section{（3） ACTH-Z 負荷反応量}

ACTH-Z 25単位筋注による負荷反応量を Table 1 と Fig. 3 に示した. P.S. Chr. はほとんどの症例は 正常域内にあるが，乙れ以下のもの 3 例，正常域以 上のもの 4 例がみられる.17-KGS では正常域以下 のものが多いが，非常に高值を示すものが 3 例ある. これは Table 3 の標準偏差が15例の健康者に比べ てかなり大きいととからもわかる，Z．Chr．の負荷 反応量は全例が正常域内にあるが，他の P.S. Chr., 17-KGS と比べるとはるかに小さい. したがつてネ 症患者の治療前の P.S. Chr., 17-KGS, Z. Chr. 負 荷反応量はいずれも対照と比べて推計学的に有意の 差はないものといえる.

\section{(4) SU-4885 試験}

治療前に SU-4885 試験をおてなつたものは 13 例中 5 例のみで, ベタメサゾン以外の合成コルチコ イド治療をうけた 3 例を加えた 8 例のネ症の P.S. Chr. の推移を Fig. 2 亿示した. 1 例は AGTH-Z および SU-4885 のいずれにも反応が低下し， 1 例 は反応遅延の傾向を示した，正常域の 3 例を除き低 下の傾向を示す．とれらは一応間脳下垂体機能不全 を示唆する成績であるが，残念ながら例数が少なく 客観性をもつとはいい難い.

\section{（5）尿量ならびに腎機能亡副腎皮質機能・予備}

\section{能}

腎疾患を対象とするかぎり，槃機能あるいは尿量と CS の尿中排泄の関係が問題となる，対象症例の腎 機能とコルチコイド治療前における尿 CS 24時間排泄量および ACTH-Z 負荷反応量との相関係数を求め ると, P.S. Chr. の24時間排泄量と尿量との間に 0.31, PSP 15分值, GFR, RPF などとは 0.47, 0.26, 0.04, 
Table 3. Response value to AGTH-Z of urinary corticosteroids in normal controls and nephrotic patients before, during \& after treatment with betamethasone.

\begin{tabular}{|c|c|c|c|c|c|c|c|c|c|}
\hline & \multirow{2}{*}{$\begin{array}{l}\text { Normal } \\
\text { Control } \\
\text { Group } \\
\text { (mg) }\end{array}$} & \multirow{2}{*}{$\begin{array}{l}\text { Before } \\
\text { Treatment } \\
\quad(\mathrm{mg})\end{array}$} & \multicolumn{5}{|c|}{$\begin{array}{c}\text { During Administration of Betamethasone } \\
(\mathrm{mg})\end{array}$} & \multicolumn{2}{|c|}{$\begin{array}{l}\text { After Treatment } \\
(\mathrm{mg})\end{array}$} \\
\hline & & & 2 Week & $\mid 1$ Month $\mid$ & 2 Month & $3 \mathrm{Month}$ & 4 Month & 1 Week & 1 Month \\
\hline P.S. Chr. & $\begin{array}{r}17.7 \\
\pm 8.0 \\
(15)\end{array}$ & $\begin{array}{r}20.1 \\
+10.9 \\
\quad(14)\end{array}$ & $\begin{array}{r}16.1 \\
\pm 7.4 \\
(10)\end{array}$ & $\begin{array}{c}10.0 \\
\pm 6.9 \\
(12)\end{array}$ & $\begin{array}{r}7.5 \\
\pm 5.9 \\
(12)\end{array}$ & $\begin{array}{r}7.3 \\
\pm 5.0 \\
(5)\end{array}$ & $\begin{array}{r}4.6 \\
\pm 4.9 \\
(5)\end{array}$ & $\begin{array}{r}12.0 \\
\pm 5.1 \\
(10)\end{array}$ & $\begin{array}{r}14.6 \\
\pm 9.4 \\
(6)\end{array}$ \\
\hline Z. chr. & $\begin{array}{r}7.7 \\
\pm 6.1 \\
(15)\end{array}$ & $\begin{array}{r}4.9 \\
+3.6 \\
(14)\end{array}$ & $\begin{array}{r}5.3 \\
\pm 3.7 \\
(10)\end{array}$ & $\begin{array}{c}4.8 \\
+3.0 \\
(12)\end{array}$ & $\begin{array}{r}3.5 \\
+3.6 \\
(12)\end{array}$ & $\begin{array}{r}2.4 \\
\pm 1.5 \\
(5)\end{array}$ & $\begin{array}{r}2.0 \\
\pm 1.3 \\
(5)\end{array}$ & $\begin{array}{r}2.4 \\
\pm 3.1 \\
(10)\end{array}$ & $\begin{array}{r}3.1 \\
\pm 2.2 \\
(6)\end{array}$ \\
\hline 17-KGS & $\begin{array}{r}25.2 \\
\pm 7.1 \\
(13) \\
\end{array}$ & $\begin{array}{r}23.0 \\
\pm 17.0 \\
\quad(14) \\
\end{array}$ & $\begin{array}{r}22.8 \\
\pm 19.6 \\
(10) \\
\end{array}$ & $\begin{array}{r}14.3 \\
\pm 12.1 \\
(12) \\
\end{array}$ & $\begin{array}{r}13.8 \\
\pm 7.7 \\
(11)\end{array}$ & $\begin{array}{r}9.5 \\
\pm 7.2 \\
(5)\end{array}$ & $\begin{array}{r}7.5 \\
+5.3 \\
(5)\end{array}$ & $\begin{array}{r}20.6 \\
\pm 7.5 \\
(10)\end{array}$ & $\begin{array}{r}21.0 \\
+15.0 \\
\quad(6)\end{array}$ \\
\hline
\end{tabular}

Each value is the mean and standard deviation of results.

Numbers in parenthesis means number of cases which were able to be examined.

AGTH-Z 負荷反応量とは一 $0.09 ，-0.21 ， 0.06 ， 0.24$ となり，対象とした症例からは明らかな相関を認め がたい.

(B) 合成コルチコイド治療中の間脳下垂体副腎皮質機能

\section{（1）尿 CS 24 時間排泄量}

合成コルチコイド治療中の副腎皮質機能を知るためには合成コルチコイドおよびそれ以外の投与薬剤の干 渉を除外するてとが必要である. 薬刜の干渉性については Borushek, 姜らの詳細な検討があるがてれは除 外しうるので，もつとも闍題になるものは治療に用いる合成コルチコイドそのもの干渉で，ての問題はとく に本邦では従来あまり注意が払われていない傾向がみられる. 三品ら ${ }^{2021)}$ はプレドニソロンを投与した患者 の P.S. Chr. 尿中排泄量と投与プレドニソロン量の間に明確な正の相関があることを示し，しかも同一患者 の投与楽剤をデキサメサゾン，トリアムシノロン，ベタメサゾンと変えるととによつて，尿 GS 排泄が低 下し，てれがてれら薬剤の P.S. 反応呈色性の低いととによることを証明した. また力価の点からプレドニ ソロンの $5 \mathrm{mg}$ はベタメサゾンの 0.5〜 0.7 $\mathrm{mg}$ に相当する力価を示すとされ，しかも投与量はプレドニソロン に比べはるかに少ない. したがつて少なくとも常用量のベタメサゾン投与中の患者尿の示す P.S. Chr., Z. Chr., 17-KGS : 実測值はいずれも患者の内因性コルチコイド分泌を反映するものであつて, 治療中の副腎 皮質機能の検査にあたつてもべタメサゾンの投与を中絶する必要はなく, 内因性コルチコイドの排泄動態を 測定しうるものと判断して差し支えない.

患者 K.S. 例（症例 7 ）について連日の尿 CS 排泄の推移を追跡した成績が Fig. 4 である. すなわちべ タメサゾン投与開始とともに尿 CS 排泄量は速やかに低下し，不規則な波状の増娍を伴なう。尿 CS 24 時 間排泄量の減少はベタメサゾン投与開始 1 週以後には著明になり，Table 2 にみられるように治療前と有意 差を示している. その後はほぼ同じレベルで推移し, ベタメサゾンの漸減投与をつづけてもあまり変化を示 さない.しかし 1 日の投与量が $1 \mathrm{mg}$ 以下となり，乙れが長期におよぶと徐々に不規則な変動を示しながら 24時間排泄量が増加する傾向がみられる. かような変化はいずれの症例にもみられるが，低下の度合には個 人差がある.

\section{(2) AGTH-Z 試験の反応パターン}

治療中の副腎皮質予備能の検索にはベタメサゾン投与をつづけながら ACTH-Z 25単位の筋注に対する尿 CS の変化をみたが，乙れはさきに述べたとおり，ベタメサゾンの投与による外因性コルチコイドの干渉を 無視しうるととにより可能となるのである. Fig. 4 亿示す症例 K.S. の治療中においても, ベタメサゾン投 与開始 $2 ， 6 ， 10$ 週‥の時点でベタメサゾン投与をつづけながら AGTH-Z 25単位の負荷試験をおてなつた. 投与 2 週後に24時間排泄量の低下をみとめるが，ACTH-Z 試験に対する反応態度はベタメサゾン投与前と 
Fig. 4. Case 7. (K.S.) 16y.o. male.

Urinary Excretion of 17-KGS, P.S. Chromogen
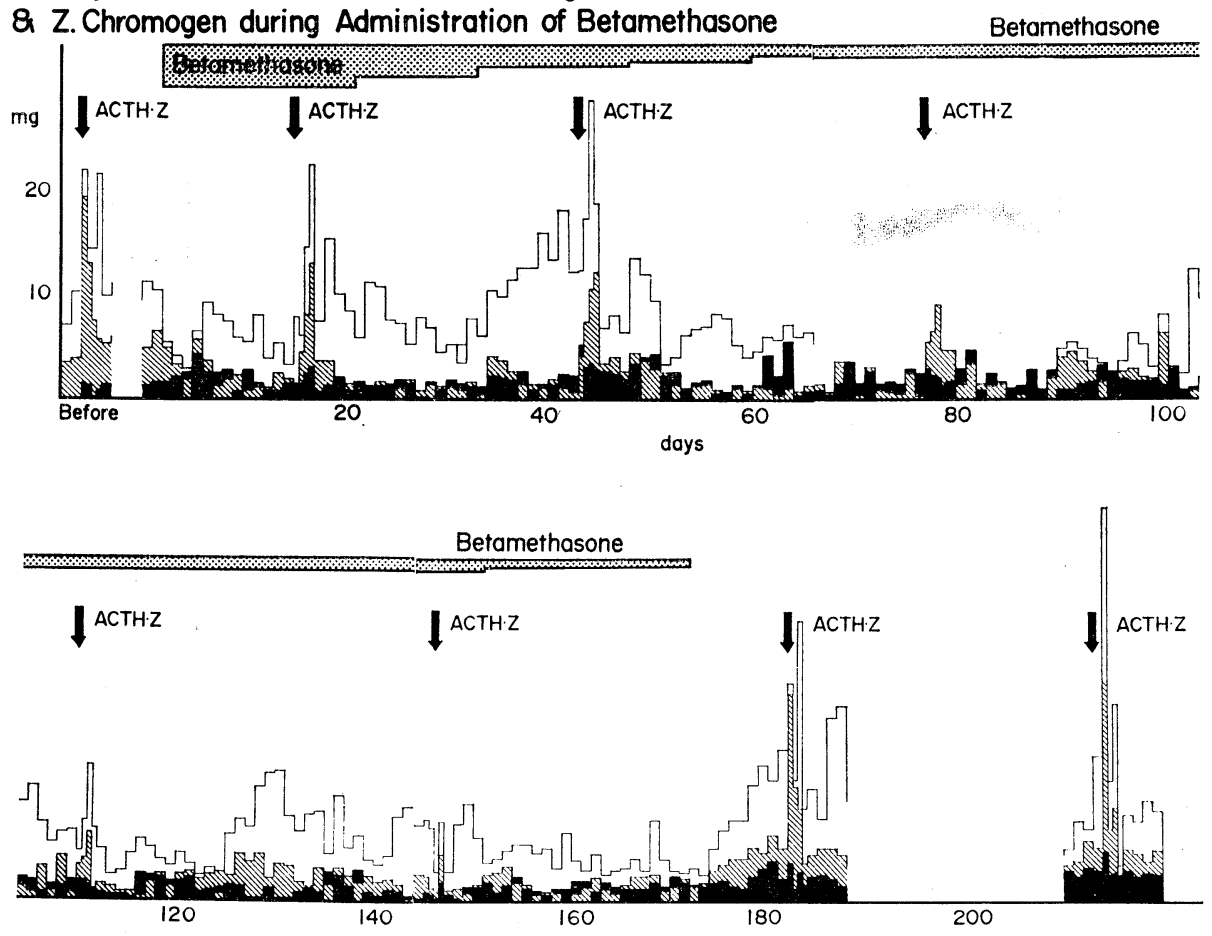

変らず著明な尿 CS 排泄の増加を示した。しかしその後治療の 経過 とともに ACTH-Z に対する反応は次 第に低下した.

検索した全亦症の治療中の ACTH-Z 試験の推移を経時的に図示したものが Fig. 5, 6, 7 である. Fig. 5 は P.S. Chr. の推移を示し，治裺経過に伴ない AGTH-Z 亿対する反応が低下遅延する傾向が著明にな る. 排泄量の最大ピークは低下し，その出現も遅延し，2 峰性のピークを示すものがみられるようになる. 症例中には早期からべタメサゾンを減量し，3 个月前後で $1 \mathrm{mg}$ 以下にしたものに，投与中にもかかわらず ACTH 反応性の回復したものがある. P.S. Chr. そみられる ACTH-Z 試験の推移は Fig. 6 の Z. Chr.,

Fig. 5.

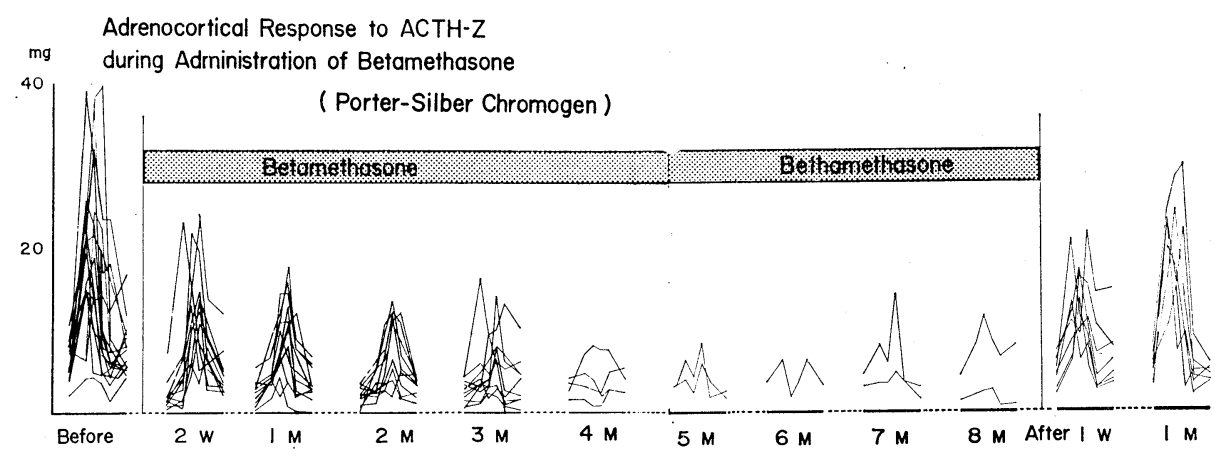


Fig. 6.

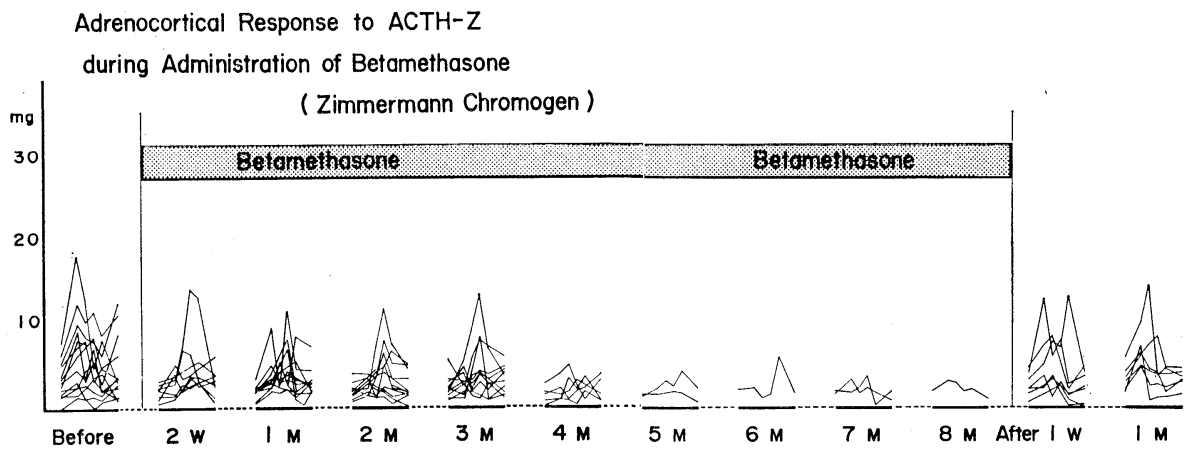

Fig. 7.

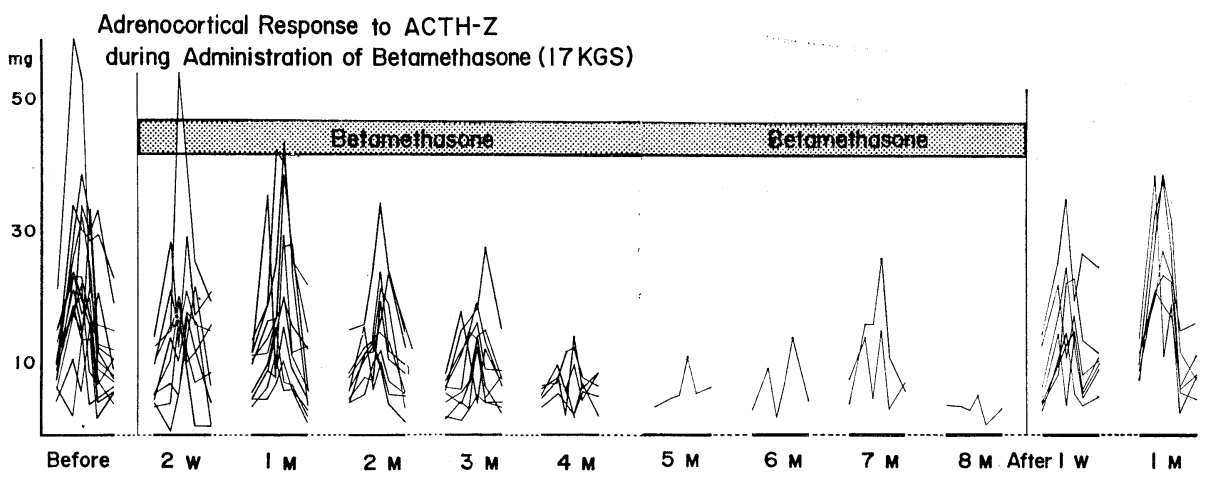

Fig. 7 の 17-KGS にも同様の傾向がみられる. 数例の症例に治療前よりもむしろ治療開始 2 週後の反応が 良好であつたものもある.

\section{（3）AGTH-Z 負荷反応量}

ベタメサゾン投与中の各時期における ACTH-Z 負荷反応量を算出し, 対象全例の平均值および標準偏差 を Table 3 に示した。 とれは Fig. 5, 6,7 に認める経時的変化を数量の変化としてとらえたものである. ACTH-Z に対する反応性は個人差が大きく，治療前值が大であればおおむね治療中の反応も大であるが， なかには治療前值が大でありながら 2 週後に低下が目立つもの (症例 $1:$ H.M.), 逆に前值よりも 2 週後の值 が大である症例も P.S. Chr. で 3 例ある. 治療前值より 2 週後の值が大である症例は，ての時期に強い利尿， 全身浮腫の著明な改善があつたととの影響も考慮せねばならぬであろう.

(G) 合成コルチコイド治療後の間脳下垂体副腎皮質機能

（1）尿 CS 24 時間排泄量

合成コルチコイド投与中止直後の尿 CS 排泄量にはかなりの変動がみられる. 三品 ${ }^{22)}$ はコルチコイド投 与中には著明に低下していた尿中排泄量が投与中止とともに一時的に上昇するものがあり，ついで再び低值 となり，その後次第に正常化するという．乙れまでにも治療後の下垂体副腎皮質機能については多数の検討 がなされてきたが，判定時期についての統一的見解はなく，中止直後におこなうべきとするもの，適当な期 間ののちにおてなうもの，さらには，一定の期間を設定せず随時検索をおこなつたものもある. 著者は治療 終了後の副腎皮質機能の判定には，中止直後の排泄量が変動する時期を避けて，7 日目の時点を選んだ. 
ベタメサゾン治療 7 日後の尿 CS 排泄量を Table 1, 2 飞示した. P.S. Chr., Z. Chr., 17-KGS のいず れも正常值を示したものは 3 例あるが，乙の時点ではなお多くの症例が正常值以下の值をとり，治療前值に 比べてとくに 17-KGS の低下が目だつが，推計学的には有意ではない.

\section{(2) AGTH-Z 試験の反応パターン}

症例K.S.の経過（Fig.4）をみるとコルチコ.イド投与140日目の AGTH-Z 試験で反応の低下遅延をみと めるが，治療終了７日後には良好な反応を示している．対象全症例の ACTH-Z 試験（Fig. 5, 6, 7, 8) 飞

Fig. 8. Hypothalamo-pituitary-adrenocortical response in nephrotic patients after treatment with betamethasone.

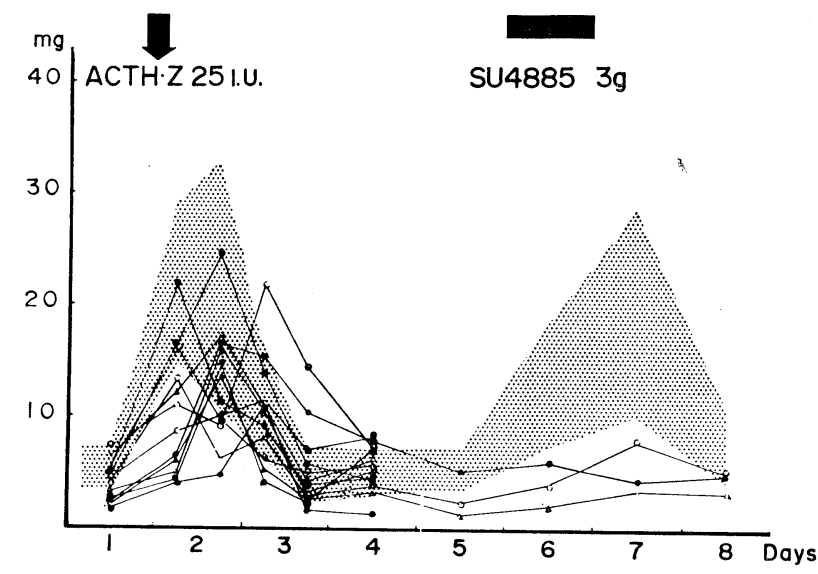

おいて，治療前には最大ピークが P.S. Ghr. で20mg前後のものが多く，30mgを超えるものもみられるが， 治療後では $20 \mathrm{mg}$ を超えるものは少ない. しかし各症例とも治療終了直前の反応に比べると著明な改善で, 明らかに可逆性であることがわかる，また 2 峰性を示すものは治療後にはなく，治療終了 1 ケ月後の反応は さらに良好であつた。

\section{（3） ACTH-Z 負荷反応量}

治療終了 7 日後の ACTH-Z 負荷反応量を Table 1 と Table 3 に示した. 多くの症例は正常值下限近 くの值を示し, かなりの個人差があるが, 治療前值との間に推計学的有意差はない. 治療 1 ケ月後の值は 1 症例を除き 1 週後の負荷反応量より大となり，回復を示す経過をとつている (Table 3).

\section{(4) SU-4885 試験}

治療終了 7 日後の ACTH-Z 試験にひきつづき SU-4885 試験をおてないえたものは 3 例のみである (Fig. 8).

1 例の ACTH-Z 試験にかなり良好に反応したものでは SU-4885 にわずかながら反応を示したが， ACTH-Z 試験に反応低下の例は SU-4885 試験に反応を示さない.つまり検索しえた 3 例はすべて不良の 反応を示したが，SU-4885 試験が副腎皮質の反応を介してのものである以上，副腎皮質反応が低下する場合， 間脳下垂体副腎皮質系の機能をてれのみでは判定し難いというべきであろう.

\section{（5）合成コルチコイド投与総量および投与日数と治療後の副腎皮質機能}

Table 1 亿示した各症例のベタメサゾンの投与総量, 投与日数と治療終了 7 日および 1 ケ月後の副腎皮質 機能との相関を Fig. 9，10 そ，相関係数を Table 4 そ一括して示した.

尿 CS 24時間排泄量, 負荷反応量のいずれにも明らかな相関はなく，とのことから治療に用いた合成コル チコイドの総量，日数と下垂体副腎皮質系の機能との間には想像されるような逆相関関係はないものといえ 
Fig. 9. Correlation between response value to ACTH-Z after treatment and sum of administered doses of betamethasone.

\section{Porter-Silber Chromogen}

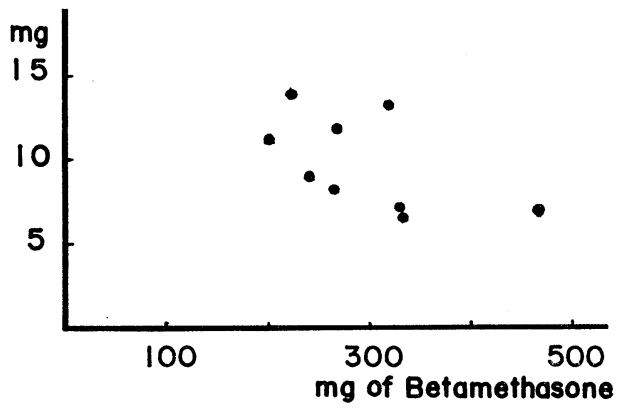

Zimmermann Chromogen

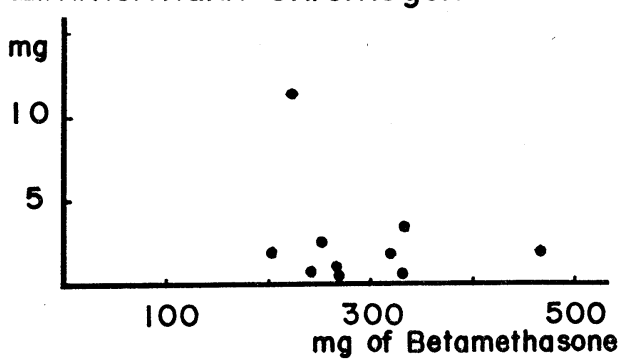

Fig. 10. Correlation between response value to ACTH-Z after treatment and duration of administration of betamethasone.
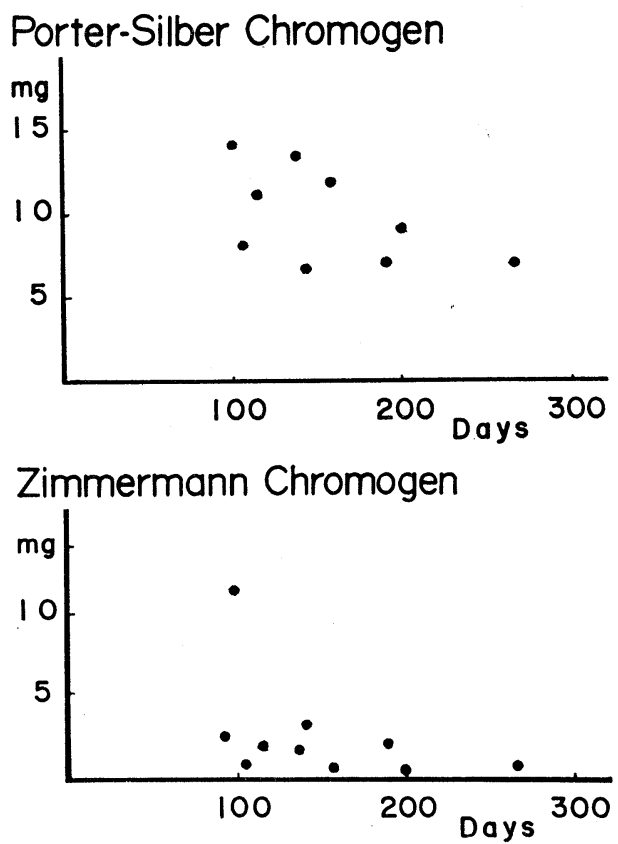

Table 4. Goefficient of correlation between adrenocortical function and its reserve and sum of administered doses of betametdasone or duration of corticoid thrapy.

\begin{tabular}{|c|c|c|c|c|c|c|c|}
\hline & & \multicolumn{3}{|c|}{$\begin{array}{l}\text { Daily Excretion of Uri- } \\
\text { nary Corticosteroids }\end{array}$} & \multicolumn{3}{|c|}{$\begin{array}{l}\text { Response Value to } \\
\text { ACTH-Z }\end{array}$} \\
\hline & & P.S. Chr. & Z. Chr. & 17-KGS & P.S. Chr. & Z. Ghr. & 17-KGS \\
\hline \multirow{2}{*}{$\begin{array}{l}\text { Sum of } \\
\text { Administered Doses } \\
\text { of Betamethasone }\end{array}$} & after 1 Week & $\begin{array}{l}0.28 \\
(10)\end{array}$ & $\begin{array}{l}-0.33 \\
(10)\end{array}$ & $\begin{array}{l}-0.31 \\
(10)\end{array}$ & $\begin{array}{l}-0.10 \\
(10)\end{array}$ & $\begin{array}{l}-0.11 \\
(10)\end{array}$ & $\begin{array}{l}-0.19 \\
(10)\end{array}$ \\
\hline & after 1 Month & $\begin{array}{l}-0.11 \\
(6)\end{array}$ & $\begin{array}{l}0.56 \\
(7)\end{array}$ & $\begin{array}{l}0.28 \\
(6)\end{array}$ & $\begin{array}{l}-0.67 \\
(6)\end{array}$ & $\begin{array}{l}-0.40 \\
(7)\end{array}$ & $\begin{array}{l}-0.50 \\
(6)\end{array}$ \\
\hline \multirow{2}{*}{$\begin{array}{l}\text { During of } \\
\text { Corticoid Therapy }\end{array}$} & after 1 Week & $\begin{array}{l}0.38 \\
(10)\end{array}$ & $\begin{array}{l}0.26 \\
(10)\end{array}$ & $\begin{array}{l}0.03 \\
(10)\end{array}$ & $\begin{array}{l}-0.24 \\
(10)\end{array}$ & $\begin{array}{l}-0.35 \\
(10)\end{array}$ & $\begin{array}{l}-0.49 \\
(10)\end{array}$ \\
\hline & after 1 Month & $\begin{array}{l}0.31 \\
(6)\end{array}$ & $\begin{array}{l}0.95 \\
(7)\end{array}$ & $\begin{array}{l}-0.04 \\
(6)\end{array}$ & $\begin{array}{l}0.13 \\
(6)\end{array}$ & $\begin{array}{l}0.09 \\
(7)\end{array}$ & $\begin{array}{l}0.27 \\
(6)\end{array}$ \\
\hline
\end{tabular}

Numbers in parenthesis means numbers of cases which were able to be examined.

よう.

上述の結果は，さきに中村 ${ }^{15)}$ が白血病のプレドニソロン大量投与患者について副腎皮質機能を検索した成 績と一致するが，またベタメサゾン以外の合成コルチコイドを投与した症例をも併せて，治療後の副腎皮質 機能を追跡した46例のネ症患者中にも治療によつて副腎皮質機能不全を示したものは 1 例もなかつたととを 附記する。 


\section{IV 考 案}

\section{（A） ネ症患者の間脳下垂体副腎皮質機能}

ネ症に ACTH や合成コルチコイドが有効であるととから，その病因と副腎皮質機能との関連は以前か ら諭議の的であつたが， Küchmeister ${ }^{23)}$ は亦症には鉱質コルチコイド優勢, 糖質コルチコイドおよびアンド ロゲン劣勢というステロイドホルモン相互の不均衡状態があり，てれがネ症病態のひとつの特徴であると同 時に，コーチゾン療法，ACTH 療法が有効である原因ともなるとした. Weisbecker ${ }^{24)}$ はネ症患者の尿 Z.

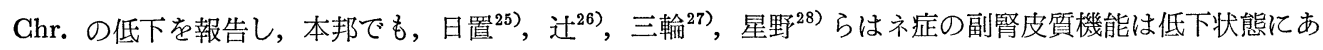
るとし, 大貫 ${ }^{29)}$ らは症状の増悪期に副腎皮質機能の低下が著明となるとし，村上 ${ }^{30)}$, 楠 ${ }^{31}$ らもその再発，再 然の原因として副腎皮質機能の低下を重視している．さらに星野のでとく，血中 P.S. Chr. レベル，AGTHZ 亿対する遅延反応を示す症例に合成コルチコイドが有効な例が多いと述べているように，現在でも Küchmeister の流れをくむ思想は跡を絶たない.

いうまでもなくネ症とは高度の蛋白尿，低蛋白血症を必須条件とし，さらに浮腫，高脂血症をともなう症 候群であつて，一般には腎機能の低下はみられないとされる.しかし症例の型によつては，また経過ととも に次第に腎機能の低下か加わる場合もある。乙れらの病態生理が㭧者の間脳下垂体副腎皮質系機能になんら かの影響を及ぼすであろうととは，むしろ当然ともいえることで，とりわけ極度の之尿が CS の排泄に及 ぼす影響も見逃しえないとてろであろう. ${ }^{35) 91)}$ ネ症の尿 CS 排泄量の減少をネ症の腎機能低下と結びつけ ようとするものも少なくない，尿 CS 排泄量と GFR との間に相関性はみられないとする Scheadle ${ }^{32)} ら の$

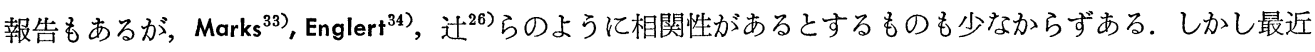
の三浦ら ${ }^{35)}$, 星野 ${ }^{28)}$ の検討では尿 CS の排泄低下は腎機能が高度に障害されたときにはじめておてるとし, GFR が $20 \mathrm{ml} / \mathrm{dl}$ 以上では, 通常, 尿 P.S. Chr. 排泄量は正常域に止まるとしている.

著者が，ここで対象とした症例について尿量，PSP 15分值，GFR 等と尿 CS 24 時間排泄量，ACTH-Z 負荷反応量などとの間の相関について検討を加えたが，相関性はまつたくみとめられなかつた。これはての 研究の対象としたネ症がさきに述べたように，すべて成人ネフローゼ症候群治療研究会の診断基準にあては まり,しかも乏尿, 浮腫はあつたが, 腎機能はほほ正常域にある症例であることによるのかも知れない。

このような症例を対象として検討した場合, 治療前のネ症患者の尿 P.S. Chr., Z. Chr., 17-KGS 24時間 排泄量, AGTH-Z 負荷反応量はほとんど正常範囲内にあつた。しかし一方，AGTH に対する反応低下を

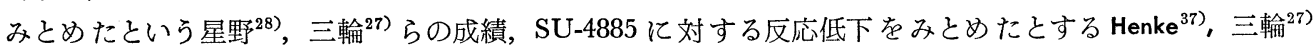
らの報告もあり，さらに辻ら ${ }^{26)}$ はネ症の血中 ACTH 活性が低下するてとを報告している。これらの ACTH 亿対する反応低下にかんしては, Streeten ${ }^{38)}$ は亦症では筋注時のみに低下し, 静注時には低下しな いとし, Filippisら ${ }^{39)}$ も筋注部位での吸収を問題にしている。しかし一方では，Geller ${ }^{40)}$ ，渋川 ${ }^{41)}$ ，星野 ${ }^{28)}$ は筋注部位での吸収には問題はないという成績をえている.

著者が研究の対象とした症例でも SU-4885 亿対する負荷反応量が低下しているという成績がえられ，乙 れは ACTH-Z 負荷反応量との関連において考えると，間脳下垂体系に機能不全が存在すると理解せざるを えない成績であるが, 少数例なので決定的な事実とはいえない. しかし全般的には症の間脳下垂体副腎皮 質系には著明な機能失調はなく，少なくともかつて病因論的にも取りあげられたネ症の副腎皮質機能低下， ないしは一次性の副腎皮質ステロイド分泌の不均衡は存在しないものと考学られる.

\section{(B) 合成コルチコイド投与中の間畄下垂体副腎皮質機能}

投与された合成コルチコイドの量が成人のコーチゾル 1 日必要量, すなわち生理的量相当量では, 副腎皮

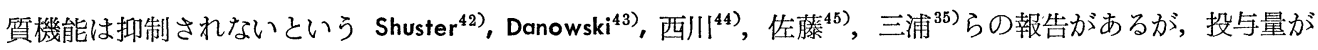
生理的量を超えるとやはり間脳下垂体副腎皮質機能は抑制されるという報告が多く，合成コルチコイド投与

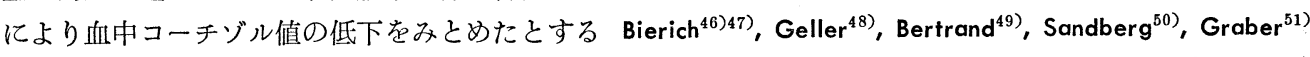

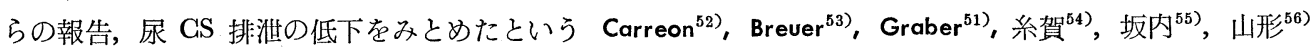
らの報告など枚挙にいとまがない。 
てのような外因性合成コルチコイドの内因性コーチゾルの分泌に対する抑制機序としては，乙れが直接副 腎皮質に作用して抑制するという Birmingham ${ }^{57)}$ ， Péron ${ }^{58)}$ らの報告に対し Sayer ${ }^{59)}$ ， Farrell ${ }^{60)}$ の実験汭 まり，多くは間脳，ついで下垂体に作用して，てれを抑制するいわゆる negative feedback mechanism に よつておてるとする実験成績が支配的である ${ }^{61) 62) 63664)}$.

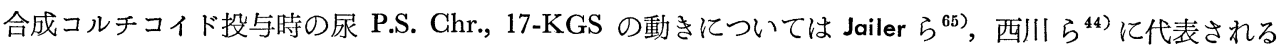
ように，投与されている合成コルチコイドの量と質とを無視したまま論じられるてとが多く，その結果とし て客観性を疑わせる業績も少なくない.三品 ${ }^{2021)}$ はての点に着目して，投与合成コルチコイドの P.S. 反応 呈色率, 概合成コルチコイドの尿中への排泄動態を追求し, 合成コルチコイド投与中に尿中へは投与したコ ルチコイドが同時に排泄され，てれが P.S. 反応呈色に関与する可能性が少なくないととを立証し，P.S. 反 応に干逤しない合成コルチコイドとして，トリアムシノロンおよびベタメサゾンをあげている．著者の研究 に投与合成コルチコイドとしてベタメサゾンのみを選んだのはての理由によるものである.

対象とした症例はベタメサゾン 3〜 5mg を初回量とした連日投与をうけているが，その尿 P.S. Chr., Z. Chr., 17-KGS 排泄量は投与数日から 7 日でろにかけて次第に低下し，その後は不規則な凹凸を示しなが ら，1〜3mg/日のレベルで推移する．しかし初回量がそのまま維持されている投与 2 週後の時点での AGTH-Z 負荷反応量は, Table 3 亿みるように治療前值とあまり有意差がないという良好な予備能を保つ ており,さらに 2 週を経過した1ケ月後の時点ではじめて反応低下を示す成績がえられ，ついで次第に ACTH 反応遅延, 負荷反応量の低下がみられるようになる. しかし漸減療法をつづけ，ベタメサゾンの投 与量が $1.0 \mathrm{mg}$ から $0.5 \mathrm{mg}$ にまで減量された時点では，すでに P.S. Chr. 排泄量は増加を示すようになり (Table 2)，間脳下垂体副腎皮質機能の回復傾向がうかがえるのである.乙れは合成コルチコイド投与中でも， 投与量がプレドニソロン $7.5 \mathrm{mg}$ 以下と $10 \mathrm{mg}$ 以上の群とでは血中 11-OHCS 值に有意差がみとめられるとす る Livanou ${ }^{66)}$ の報告, 漸减療法で投与量がプレドニソロン $5 \mathrm{mg}$ 以下となつた場合にはほとんどの症例の血 中コーチゾル值は正常化するという Daly ${ }^{67)}$ の成績に一致する所見とも考孚られる.

合成コルチコイド治療後におてる副腎皮質機能不全に由来すると考元られるショック死が Fraser ${ }^{88)}$ ， Salassa $^{69)}$ ， Lewis ${ }^{70)}$, Harnagel ${ }^{71)}$ ，Kushlan \& Hayes $^{72)}$ ，Christy ${ }^{73)}$, Slaney ${ }^{74)}$ ，Allanby ${ }^{75)}$ ，梅原 ${ }^{76)}$ らによつて報告 されている.しかしてれらの危険は合成コルチコイド治療を中止した後に間脳下垂体副腎皮質機能検查を実 施したのでは遅きに過ずるうらみがあり, 臨床家はやはり合成コルチコイド治療中から患者の間脳下垂体副 腎皮質機能動態，副腎皮質予備能を注意深くとらえ，それにもとづいた慎重な合成コルチコイドの離脱をは かるべきであろう。との研究で著者がえたベタメサゾン治療中のネ症患者の治療開始後の一定間隔での ACTH-Z 負荷反応量の経過は医原性副腎皮質機能不全による事故をおこすととなく，しかも間脳下垂体副 腎皮質系機能の抑制が可逆性であつた症例群のひとつの基準を提示しえたものと考える.

(C) 合成コルチコイド治療終了後の間脳下垂体副腎皮質機能動態

合成コルチコイド投与中止後の副腎皮質機能を検討した報告は数多く，その多くは中止後の血中，または 尿中 CS 值をもつて判定している. しかし合成コルチコイド投与中止後のいかなる時点での測定值が患者の 副腎皮質機能をあらわすかの問題はきわめて困難な課題である.

合成コルチコイド投与中止直後の血中 P.S. Chr., あるいはコーチゾル分泌量は正常域内にあつたとする Christy ${ }^{73)}$ ，Robinson ${ }^{77)}$ らの報告もあるが，多くは血中コーチゾル值 ${ }^{46) ~}{ }^{51)}$ ，尿 CS 排泄量 ${ }^{51) 52(53)}$ は低下すると している.しかし中止直後では低下しても短時日内に急速に正常化するという報告も少なくない. Bierich ${ }^{46)}$ 47) はコルチコイド投与中止 4〜 7 日後に患児の血中 P.S. Chr. 值は正常化するとし, Breuer ${ }^{533}$ は 2〜5日で尿 P.S. Chr., Z. Chr. は治療前值に復するという. 同様の尿 P.S. Chr. の経過は糸賀ら ${ }^{54)}$, 西川 ${ }^{44)}$, 三品 ${ }^{22}$ によつても報告されており,三品は尿 P.S. Chr. 24時間排泄量は治療終了 3 〜 日後の時点で反撥し,いつた ん正常化するが,再び低下するという経過をとり,その後徐々に正常化するという現象について報告している.

したがつて著者の研究では合成コルチコイド治療終了後の ACTH-Z 試験を治療終了後 7 日後の時点にお てない，さきの反撥現象のおてる時期を避けて ACTH-Z 負荷反応量の計出を意図した．そして治療終了 1 
週後の時点での負荷反応量は Table 3 にみられるように，P.S. Chr. はわずかに治療前值に劣るが，17KGS はほとんど変化しないという成績をおさめ，Z．Chr. は治療前值に比べて低下がみとめられた。治療 終了1 1 ケ後の副腎皮質予備能はさらに回復するが, 治療前值をわずかに下廻るという成績である。しかし てれらの症例中から，その後副腎皮質機能不全にもとづくと考光られる事故は発生せず，昭和46年末に至る まで，ネ症の再発，再燃はさておき，副腎皮質機能にかんするかぎり良好な経過をたどつている.

治療終了後の副腎皮質機能々かんしては，Bierich ${ }^{46) 47}$ ，Sprague ${ }^{78)}$ ，糸賀 ${ }^{54)}$ らは 1 週以内に回復するといい, Carreor ${ }^{52)}$ は治療 1 ケ月後の時点で治療患者の 4 分の 3 が正常化するとし, Vermeulen ${ }^{79)}$ も臨床的には副腎 皮質機能不全を示さないが，少なくとも1 ケ月間は反応性の減弱が存在し，Subclinical な不全状態にある という. しかし反応低下はさらに長期にわたり存在するという報告も多く, 数ヶ月はつづくという井林 ${ }^{5)}$,

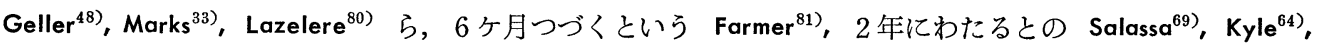
Bayliss ${ }^{82}$ らの報告もある.

さらに外因性の合成コルチコイドによる機能の抑制は副腎皮質のみならず，間脳下垂体にも及ぶとてろか ら, 間脳下垂体機能あるいはその予備能を検討するてとの必要性がみとめられている，その意味において SU-4885 試験をおこない，合成コルチコイド治療後们間脳下垂体予備能の低下をみとめるとする Liddle ${ }^{83}$ ， Farmer $^{81)}$, Janches ${ }^{84}$ ，Treadwell ${ }^{85)}$ ，三宅 ${ }^{86)}$ ，中村 ${ }^{15)}$ らの成績があり，Meakin ${ }^{87)}$ のごとく下垂体の回復が早い とするものもあるが，一般に SU-4885 亿対する反応からうかがえる間脳下垂体予備能は ACTH-Z に対す る反応から判定される副腎皮質予備能より遅れて回復に向かうといわれる。 そして Farmer ${ }^{81}$ ， Janches ${ }^{84}$ ，中 村 ${ }^{15)}$ ら SU-4885 負荷に対する反応と，治療に用いた合成コルチコイドの投与総量，あるいは投与期間と の間にはなんらの相関性はみられないという。

(D) 合成コルチコイド治療後の間脳下垂体副腎皮質機能と投与総量あるいは投与期間との相関性

合成コルチコイド治療後の副腎皮質機能低下と治療に用いた合成コルチコイドの投与量，投与期間につい ては，はじめ Bennet ${ }^{88)}$ ， O'Donnel ${ }^{89)}$ らが剖検例の副腎皮質の萎縮度が投与量ならびに 投与期間に比例して 強くなるてとを報告し，Ingle ${ }^{90)}$ が投与総量との相関を実験的に証明して以来，多くの研究者によつて検討 されたが，臨床的には治潦後の副腎皮質機能低下，あるいは間脸下垂体副腎皮質機能の低下と投与期間とが

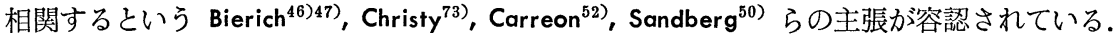

著者の研究の対象とした症例のすべてがネ症であつたてと，しかも全症例のベタメサゾン投与量の範囲が 203.5から509.75mg，投与期間が76から535日であつたためか，その治療 1 週間後の尿 P.S. Chr., Z. Chr., 17-KGS 24時間排泄量, 尿 P.S. Chr., Z. Chr., 17-KGS から測定した AGTH-Z 負荷反応量と上にのべた 投与総量，投与期間との間には Table 4 にみられるとおり相関性はまずないという成績であつた。.とれは プレドニソロン投与総量が 0.18 か $59.4 \mathrm{gm}$ にわたり，投与期間が 1 から 125 ケに及ぶ症例を対象とした Treadwell ${ }^{85)}$ の成績と比べると投与期間がきわめて限定された症例を対象として検討したてとになり，相関 性がみられなかつたととはむしろ当然といえるかも知れない，一方 Treadwell はさきにものべたように， 投与期間でいえば 1 ケ月から10年 5 ケ月に及ぶといら大きなひらきのある対象について SU-4885 負荷反応 量を測定し，投与総量，投与期間と SU-4885 負荷反応量との間には大まかな相関がみられるとし，不全例 が 1 年 3 ケ月以上のプレドニソロン投与例にみとめられたてとを報告している. 要するに著者の成績と Treadwell の結論の相違は対象の治療期間，治療薬量の分布範囲のひらきの差異に 起因するものと考元ら れるのである. Treadwell の対象に比べると，著者が対象とした症例はすべてがほぼ⿵じような巾の狭い 投与量，投与期間の合成コルチコイド治療をうけており，てのような対象からは合成コルチコイドの投与総 量, 投与期間と治療後の副腎皮質機能との間には一定の関係をひき出しえず，むしろ対象の個人差を強調せ ざるをえない結果佟つたといえよう。

しかし，てのととはきわめて重要なととのように思えるが，著者が経験したとてろのせいぜいベタメサゾ ン投与量 203.5 から $509.75 \mathrm{mg}$ ，投与期間 76から535日という範囲での合成コルチコイド治療では，むしろ 㭧者の個人差を十分に重視すべきであろう。つまり個人差を無視した画一的な予防，あるいは治療法は有害 
でこそあれ，益はないといえよう．臨床家は合成コルチコイド治療にあたつて，症例でとに間脳下垂体副腎 皮質機能, とくに離脱期あるいは治療前後における患者の間脳下垂体副腎皮質系機能動態を観察し，正確な 認識のうえに立つた正しい対策を講ずるべきであうう。また副緊皮質機能低下例では正常化までその副腎皮 質機能を追跡するととは臨床家の当然はたすべき義務と考える.

\section{$\mathrm{V}$ ま $め$}

昭和 39 年から 42 年までの 4 年間に京都府立医科大学第二内科に入院したネ症患者 13 症例にベタメサゾン治 療をおこない，その治療前，中，後にわたつて，尿 P.S. Chr., Z. Chr., 17-KGS を経時的に測定し，同時 に AGTH-Z 負荷による間脳下垂体副腎皮質予備能の変化を追求しつぎの結論をえた。

（1）初回治療前，再発時治療前尿 CS 24時間排泄量， ACTH-Z 負荷反応量， SU-4885 負荷反応量なぞ からみたネ症の間脳下垂体副梷皮質系機能は，SU-4885 負荷反応量に低下㖽向がみられる以外，ほとんど正 常範囲内にあり，かつて病因論的にも主張されたととのあるネ症における副腎皮質機能の低下は認められな かつた.

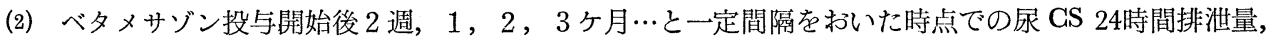
AGTH-Z 負荷反応量は，治療前值が大であつたものでは治療中も大で，その個人差が目だつ． 全症例の経 過をみると投与開始当初から尿 24 時間排泄量は低下するが, ACTH-Z 負荷反応量は大で，その後治療経過

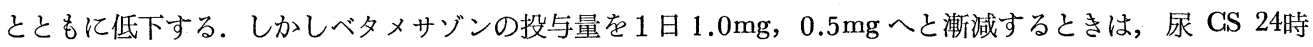
間排泄量が投与終了に先立つてすでに増量し，ACTH-Z 負荷反応量も回復傾向を示すものがある.

（3）投与終了1 週，1 个月後の時点での ACTH-Z 負荷，SU-4885 負荷による間脳下垂体副䶤皮質予備 能検查を行なつた. 合成コルチコイド中止後の尿 CS 排泄量は投与終了後 $2 \sim 6$ 日後の間にいつたん上昇 し，ついで再び低值となり，その後は次第に正常化する.

ベタメサゾン治療終了 7 日後の 24 時間排泄量はなお低值を示し, ACTH-Z 負荷反応量は正常域下限に近 い值を示すものが多いが，治療前の負荷反応量との間には推計学的に有意差をみとめなかつた。

治療 1 ケ月後の負荷反応量は 1 例を除き 1 週後の值より大で, 回復を示す経過をとつた. 少数例ではある が SU-4885 負荷反応量は低值をとつたものがあつた.

（4）投与終了 7 日後の AGTH-Z 負荷反応量とベタメサゾン投与総量，投与期間との相関性は著者の研究 の対象となつた症例にみるかぎりみられず，投与総量が多く，投与期間が長くても負荷反応量が低下すると いうことはなかつた．乙れは対象となつた症例がすべて同一疾患であり，投与総量203.5から509.75 mg，投 与日数76から535日というかなり限局した範囲の治療であつたとてろにあり，てれがむしろ対象の個人差を 大きく浮彫りにするという結果になつたものと考える.

(5) とのようにベタメサゾンの 3 ないし18ケ月にわたる投与によつておてるとてろの副腎皮質機能低下は 軽度で，すべて可逆性であり，てれらの症例は昭和46年末に至るまで間脳下垂体副腎皮質不全に起因すると 考えられる不慮の事故を経験しておらない.しかしてれが今後のすべてのネ症の合成コルチコイド療法にあ てはまるとは考苀い，合成コルチコイド療法にあたつては，やはり今後とも症例でとの，とくに楽剤の離 脱期における間脳下垂体副腎皮質機能および子備能を検査するてとが大切であつて，もしも機能低下の傾向 がみとめられた場合には，その正常化まで間脳下垂体副腎皮質機能を追跡管理するてとが肝要である.

稿を終わるにあたり，御指導，御校閲を賜わつた恩師丸本晋教授に澡く感謝すると共に，研究当初より御 教示, 御指導頂きました三品賴甫講師, 実験に当り色々之御協力頂いた中村充男博士ならびに教室内分泌研 究グループの諸先生に心から感謝の意を表します.

\section{参 考 文 献}

1) Hench, P.S., et al. : Proc. Staff. Meat. Mayo Clin., 24 : 181, (1949)

2) Thorn, G., et al. : 
Arch. Int. Med., 86 : 319, (1950)

3) Farnsworth, E.B. : Proc. Soc. Exp. Biol. \& Med., 74 : 57, (1950)

4) DiRaimondo, V.C., et al. : Metabolism, $7: 5$, (1958)

5) 井林 博, 他 : 日

臨, $18: 591,(1960)$

6) Reddy, W.J., et al. : Metabolism, $1: 511$, (1952)

7) 熊谷

朗, 他 : 内科, $8: 879$, (1961)

8) Sobel, G., et al. : J. Glin. Endocr., $18: 208$, (1958)

岡田弘二, 他：日内分泌会誌，41：856，（1965）

10) Norymberski, J.K., et al. : Lancet I : 1276,

（1953）11）渡辺富久子：奈良医誌，11：911，(1960）

(1961)

13）魚住 徹, 他：日内分泌会誌, 37 :436, (1962)
12）熊谷 朗, 他 : 㟝療, $14: 33$,

14) 河野 剛, 他: 最新医学, $19: 165$, (1964)

15）中村充男：日内分泌会誌，43：1044，(1968).

16) Borushek, S.,

et al. : Glin. Chem., $10: 41$, (1964)

17）三品頼甫，他：臨床病理，14：366，（1966）

姜 行捷, 他：日内分泌会誌, $42: 255$, (1966).

20）三品頼甫，他：ホルモンと瀶床，14：465, (1966).
22）三品頼甫, 他：日内分泌会誌，40：413，(1964）.
(1967)
23) Küchmeister, H. :

19）姜 行捷：日内分泌会誌，45：208（1969）.

21）三品頼甫，他：日内会誌，56:1115,

Patholog. Physiologie und Klinik d. Nierensekretion (1955), Springer, Berlin.

L. : Probleme d. Hypophysen-Nebennierenrinden-systems (1953), Springer, Berlin.

24) Weisbecker,

25）日置

陸奥夫：日内分泌会誌，32：316，（1956）

27）三輪清三，他：日内分泌会誌，40：416，（1964）

29）大貫 稔, 他：日腎会誌， $8: 133 ，(1966 ）$
26）辻 昇三，他：日腎会誌，5：124，（1963）

28）星野恒夫：日腎会誌，8：463，（1966）

30）村上勝美：小児の腎疾患（1963），中外医学 : J. Clin. Endocr., 19 : 1223, (1959) 33) Marks, L.J., et al. : J. Clin. Invest., $32: 813$, (1953) 34) Englert, E., et al. : J. Clin. Endocr., 18:36, (1958) 35）三浦 清, 他 : 日内会誌, $51: 634$ (1962) 36) Kalant, T.N. : Am. J. Physiology, $182: 503$, (1953) 37) Henke, W.J., et al. : J. Clin. Endocr., 27 : 1567, (1967) 38) Streeten, D.H., et al. : Clin. Res. Proc., 3 : 201, (1955) 39) Filippis, V.D., et al. : New Eng. J. Med., $257: 1$, (1957) 40) Geller, J., et al. : J. Clin. Endocr., $17: 390$, (1957) 41）渋川直次：日内分泌会誌, $37: 1052$, (1962). 42) Shuster, S., et al. : Lancet II : 674, (1961) 43) Danowski, T.S., et al. : Ann. Intern. Med.,

45）佐藤昭雄 : ホルモ ンと臨床, $13: 39$, (1965) 46) Bierich, J.R., et al. : Acta Endocr., $31: 40$, (1959)

Bierich, J.R., et al. : Dtsch. Med. Wschr., 87 : 84, (1962) $\quad$ 48) Geller, J., et al. : J.C.E.M., 18 : 409, (1959)

49) Bertrand, J., et al. : J. Pediat., $57: 471$, (1960)

50) Sandberg,

A.A., et al. : J. Lab. Glin. Med., 50 : 286, (1957)

51) Graber, A.L., et al. : J. Glin. Endocr., $25: 11$, (1965)

52) Carreon, G.G., et al. : J. Lab. Clin. Med., $56: 235$, (1960)

53)

Breuer, H., et al. : Arzneimittelforschung, $11:$ 747, (1961)

54）糸賀宣三, 他 : 内科, $9: 493$,

(1962).

55）坂内 昇：新潟医会誌， $74: 1291 ，(1960)$.

56) 山形敞一, 他 : ホルモンと 臨床, $10: 265$, (1962).

57) Birmingham, M.K. : Endocr., $62: 47$, (1958)

58) Péron,

F.G., et al.: Endocr., $67: 379$, (1960) 59) Sayers, G. \& Sayers, M.K. : Ann. New York Acad. Sc., $50: 522$, (1949) 60) Farrell, G.L., et al. : Endocr., $56: 471$, (1955)

61) Bethune, J.E., et al. : J. Clin. Invest., $36: 1701$, (1957) 62) Holub, D.A., et al. : J. Glin .Invest., 38 : 291, (1959) 63) Kitay, J.I., et al. : Endocr., $64: 475$, (1959) 64) Kyle, L.H., et al. : New Eng. J. Med., 257 : 57, (1957) 65) Jailer, J.W., et al. : Am. J. Med., $16: 340$, (1954) 66) Livanou, T., et al. : Lancet : 856, (1967) 67) Daly, J.R., et al. : Ann. Rheum. Dis., 26 : 18, (1967) 68) Fraser, C.G., et al. : J.A.M. A., 149 : 1542, (1952) 69) Salassa, R.M., et al. : J.A.M.A., 152 : 1509, (1953) 70) Lewis, L., et al. : Ann. Int. Med. 39 : 116, (1953)

71) Harnagel, E.E.,et al. : J.A.M.A., 158 : 1518, (1955)

72) Hayes, 
M.A., et al. : Gastroenterology, $30: 75$, (1956)

(1956)
73) Ghristy, N.P., et al. : J.C.E.M., $16: 1059$,

Lancet I : 1104, (1957)

76）梅原千治, 他：最新医学, $13: 1456$, (1958)

75) Allanby, K.D., et al. :

B.H.B., et al. : Brit. Med. J., 1 : 1579, (1962)

78) Sprague, R.G., et al. : Arch. Int. Med., 85 : 199, (1950)

79) Vermeulen, A. : Acta Endocr., $28: 321$, (1958)

80) Larzelere,

R.G. Jr., et al. : Arch. Intern. Med., 99 : 888, (1957)

81) Farmer, T.A., et al. : J. Clin. Endocr., $21: 433$, (1961)

82) Bayliss, R.I.S., et al. : Brit. Med. J., 2 : 935, (1958)

Liddle, G.W., et al. : J. Glin. Endocr., 19 : 875, (1959)

84) Janches, M., et al. : J.C.E.M., 25 : 534, (1965)

85) Treadwell, B.L.J., et al. : Lancet I : 355, (1963)

86）三宅 儀, 他 :

最新医学, $19: 524,(1964)$.

87) Meakin, J.W., et al. : Am. J. Med., 29 : 459, (1960)

88) Bennett, W.A. : J. Bone Joint Surg., 36A : 867, (1954)

89) O'Donnell, W.M., et

al. : Arch. Intern. Med., 88 : 28, (1951)

90) Ingle, D.J., et al. : Anat. Res., $71: 363$, (1938)

91) Lloyd, C.W. : Rec. Prog. in Hormone Res., 7 : 469, (1952) 